\title{
ORGANIC MATTER AND SOIL FERTILITY IN DIFFERENT SUCCESSIONAL STAGES OF SEASONAL SEMIDECIDUAL FOREST ${ }^{1}$
}

\author{
DEIVID LOPES MACHADO ${ }^{2 *}$, MARCOS GERVASIO PEREIRA ${ }^{3}$, LAUANA LOPES DOS SANTOS $^{4}$, ANDERSON \\ RIBEIRO DINIZ ${ }^{3}$, RONI FERNANDES GUARESCHI ${ }^{3}$
}

\begin{abstract}
The accumulation and transformation of organic matter in the soil are fundamental for the maintenance and improvement of the chemical, physical, and biological attributes of the soil, and consequently, for the tropical forests functioning. The objective of this study was to evaluate the influence of secondary forests with different successional stages on soil organic matter, carbon and nitrogen stocks, and soil fertility. Three areas of seasonal semideciduous forest, located in Pinheiral - RJ, with different successional stages were selected: initial stage forest - ISF, medium stage forest - MSF, and advanced stage forest - ASF. The values of total carbon and nitrogen, $\mathrm{C}$ and $\mathrm{N}$ stocks, $\delta^{13} \mathrm{C}(\%)$ isotope, chemical and granulometric fractionation of soil organic matter, and soil fertility were determined. Based on the values of $\delta^{13} \mathrm{C}(\%)$, it was verified that most of the soil carbon of the different successional stages comes from forest species $\left(\mathrm{C}_{3}\right.$ plants $)$. The areas with the highest succession time (MSF and ASF) possess higher levels of carbon and nitrogen contents and stocks, and carbon associated with minerals compared to ISF. In addition, ASF showed increased phosphorus, fulvic acid, humic acid, whereas soil density exhibited reduced values when compared to that of other areas. The MSF showed, in general, greater fertility of the soil. This study emphasizes the importance of secondary forests that, even in the initial stages of succession, have great potential to store and stabilize organic carbon in the soil.
\end{abstract}

Keywords: Soil atributes. Organic matter fractionating. Carbon stock. Forest succession. Atlantic forest.

\section{MATÉRIA ORGÂNICA E FERTILIDADE DO SOLO EM DIFERENTES ESTÁDIOS SUCESSIONAIS DA FLORESTA ESTACIONAL SEMIDECIDUAL}

RESUMO - O acúmulo e as transformações da matéria orgânica do solo são fundamentais para a manutenção e melhoria dos atributos químicos, físicos e biológicos do solo, e, consequentemente, para o funcionamento das florestas tropicais. O objetivo deste estudo foi avaliar a influência de florestas secundárias com diferentes estádios sucessionais na matéria orgânica do solo, nos estoques de carbono e nitrogênio e na fertilidade do solo. Foram selecionadas três áreas de Floresta Estacional Semidecidual, com diferentes estádios sucessionais, sendo estas: floresta em estádio inicial - FEI, floresta em estádio médio - MSF e floresta em estádio avançado - FEA, localizadas em Pinheiral, RJ. Foram determinados os valores de carbono e nitrogênio total, estoques de $\mathrm{C}$ e nitrogênio, isótopo $\delta^{13} \mathrm{C}(\%)$, fracionamento químico e granulométrico da matéria orgânica do solo e fertilidade do solo. Por meio dos valores do isótopo $\delta^{13} \mathrm{C}(\%)$ verificou-se que a maior parte do carbono do solo dos diferentes estádios sucessionais é oriunda das espécies florestais (plantas C3). As áreas com maior tempo de sucessão (FEM e FEA) promoveram maiores teores e estoques de carbono e nitrogênio, e carbono associado aos minerais em comparação à ISF. Adicionalmente, na FEA observaram-se aumentos dos teores de fósforo, ácido fúlvico, ácido húmico e redução dos valores de densidade do solo quando comparada as demais áreas. A FEM apresentou, de maneira geral, maior fertilidade do solo. Este estudo destaca a importância das florestas secundárias que, mesmo em fases iniciais de sucessão, possuem grande potencial em estocar e estabilizar carbono orgânico no solo.

Palavras-chave: Atributos edáficos. Fracionamento da matéria orgânica. Estoque de carbono. Sucessão florestal. Mata atlântica.

\footnotetext{
${ }^{*}$ Corresponding author

${ }^{1}$ Received for publication in $05 / 11 / 2017$; accepted in 08/08/2018.

Paper extracted from the master dissertation of the first author.

${ }^{2}$ Department of Forest Engineering, Universidade Federal de Goiás, Jataí, GO, Brazil; deividflorestal@gmail.com - ORCID: 0000-00020567-4288.

${ }^{3}$ Department of Soils, Universidade Federal Rural do Rio de Janeiro, Seropédica, RJ, Brazil; gervasio@ufrrj.br - ORCID: 0000-0002-14023612, andersonribeiro02@gmail.com - ORCID: 0000-0002-8471-5120, guareschiecotarelli@hotmail.com - ORCID: 0000-0002-41229405 .

${ }^{4}$ Department of Agronomy and Forest Engineering, Universidade Federal dos Vales do Jequitinhonha e Mucuri, Diamantina, MG, Brazil; lauanasantos@ymail.com - ORCID: 0000-0002-8788-9951.
} 


\section{INTRODUCTION}

Deforestation for agricultural use followed by livestock farming in regions of rugged relief may lead to landscapes with different degrees of degradation. As a consequence, there is a decrease in soil water retention capacity, low soil stability, reduction in fertility levels, decrease in carbon and nitrogen stocks, and intensification of erosion processes, with the latter as the main indicator of degradation in these areas (LAL, 2005; MACEDO et al., 2008; MACHADO et al., 2010).

Soil carbon losses (C) resulting from the conversion of tropical forest to agricultural use can be recovered through the establishment of secondary forests (LAL, 2005; SCHEDLBAUER; KAVANAGH, 2008). With successional dynamics, forests present changes in the composition and richness of plant species and increases in the structural complexity of vegetation (CHAZDON, 2012). These changes in forest vegetation are also accompanied by changes in litter production and stock (MACHADO et al., 2015), and consequently with increasing nutrient contents and carbon and nitrogen stocks of soil (GUARIGUATA; OSTERTAG, 2001). Among the main factors influencing the increase in soil carbon and nitrogen contents, studies have highlighted significant effects of plant biodiversity ((GAMFELDT et al., 2015); ZUO et al., 2015) and the role of leguminous species, as a function of their ability to associate with nitrogen-fixing bacteria and to produce significant amounts of biomass (MACEDO et al., 2008; WANG et al., 2010).

Most of the studies on soil organic carbon emphasize the influence of different management practices on soil carbon and nitrogen stocks. A more specific way of assessing total organic carbon (TOC), and hence of testing the effects of land use and management practices on soil quality, is related to the understanding of soil carbon stability. Studies on soil organic matter (SOM) compartments, such as the carbon of humic substances and the carbon associated with sand, silt, and clay fractions, have been used as indicators of changes in land use, because they are sensitive enough to detect changes in soil management (CAMBARDELLA; ELLIOT, 1992; FONTANA et al., 2006). Regarding the granulometric fractionation of soil organic matter (SOM), there are few studies evaluating this technique in forest areas, which demonstrates the need for studies in these ecosystems, since these SOM fractions are the most sensitive to verify changes in soil use (LOSS et al., 2012; ROCHA JÚNIOR et al., 2014).

The significant vegetal residues input to the forest floor is one of the main factors that contributes to the greater fertility of the soil in tropical forests, and consequently, increase in the soil organic matter contents (GUARESCHI et al., 2014). However, there are still few studies that evaluate the dynamics of soil organic matter and soil fertility throughout the successional process, especially in difficult access areas, located in high hills. Therefore, the objective of this study was to evaluate the influence of different successional stages of the Atlantic Forest on the compartmentalization of soil organic matter, soil carbon stocks, and soil fertility in the region of 'Mar de Morros', Pinheiral - RJ. The main hypothesis guiding this investigation was that the more advanced successional stages store and stabilize more organic carbon, in addition to having greater natural fertility than the initial successional stages.

\section{MATERIAL AND METHODS}

\section{Location and characterization of study areas}

The study was carried out in the municipality of Pinheiral, RJ, in the region of the Middle Paraíba Fluminense, in the sub-basin of Ribeirão Cachimbal, which composes the Paraíba do Sul river basin, located between latitudes $22^{\circ} 29^{\prime} 03^{\prime \prime} S$ and $22^{\circ}$ $35^{\prime} 27^{\prime \prime} \mathrm{S}$ and between longitudes $43^{\circ} 54^{\prime} 49^{\prime \prime} \mathrm{W}$ and $44^{\circ} 04^{\prime} 05^{\prime \prime} \mathrm{W}$.

The climate of the region, according to the classification of Köppen, is identified in two distinct ways, in Cwa- temperate climate with dry winters and rainy summers and Am- rainy tropical climate with dry winters (ALVARES; STAPE; SENTELHAS, 2013). The region experiences annual precipitation of $1,300 \mathrm{~mm}$ and average annual temperature of $21^{\circ} \mathrm{C}$.

The region is part of the Atlantic Forest biome. The original vegetation of this region is called Semidecidual Submontane Seasonal Forest (IBGE, 2012), characteristic of altitudes between 300 and $800 \mathrm{~m}$. The region is also in the morphoclimatic domain of 'Mar de Morros', characterized by dissected hills and rounded hill tops (AB'SABER, 1996). The current vegetative cover in the region consists of secondary forest fragments with different successional stages within unmanaged and spontaneous managed pasture matrices, which present in different stages of degradation, level of use, and/or abandonment (MENEZES et al., 2010).

In this study, three areas of secondary forests were evaluated, which compose a single forest fragment of Atlantic Forest, of approximately 190 ha. Forests were found in different successional stages, namely: initial stage forest (ISF) with approximately 20 years of succession; middle stage forest (MSF) with approximately 25 years of succession, and advanced stage forest (ASF) with approximately 60 years of succession (MACHADO et al., 2015).

According to the Brazilian Soil Classification System (SANTOS et al., 2013), the soils identified in 
the study units were classified as typical Cambissolo Háplico Distrófico Tb (MENEZES et al., 2010), one of the predominant classes in the uppermost subbasin. The studied areas are located in the upper third of the slope, have a southeastern facing exposure, and declivity between $50-70 \%$.

\section{Soil sampling and analysis}

A representative plot of 0.09 ha $(30 \times 30 \mathrm{~m})$ was demarcated in each study area, and five trenches of approximately $1 \times 1 \mathrm{~m}$ of surface and $1 \mathrm{~m}$ of depth were opened in each one in a random position. The samples were collected in March 2009. In each of the trenches, undisturbed samples were collected with the aid of a volumetric ring (DONAGEMMA et al., 2011) at the depths of 0.0-0.10 and 0.10-0.20 m. At these depths, deformed samples were also collected, which were air-dried, crushed and passed through a $2 \mathrm{~mm}$ mesh screen, obtaining the air-dried fine earth, in which most of the analyses were performed, including chemical characterization and granulometric analysis (DONAGEMMA et al., 2011). The textural classes of the areas were evaluated based on the values of sand, silt, and clay, in the different layers evaluated. The ISF was classified as loamy loam and MSF and ASF as sandy loam. The samples were used to characterize the chemical attributes of the soil. Thus, the following determinations were made: $\mathrm{pH}$ in water, potential acidity $(\mathrm{H}+\mathrm{Al}), \mathrm{Ca}^{2+}, \mathrm{Mg}^{2+}, \mathrm{Na}^{+}, \mathrm{K}^{+}$, and $\mathrm{Al}^{3+}$. The chemical analyses were performed according to Donagemma et al. (2011). The sum of bases - Value $\mathrm{S}\left(\mathrm{Ca}^{2+}+\mathrm{Mg}^{2+}+\mathrm{Na}^{+}+\mathrm{K}^{+}\right)$and base saturation V\% (= Value S/Value T)*100 were calculated.

Bulk density (BD) was determined using the volumetric ring method (Donagemma et al., 2011). Total organic carbon contents (TOC) were quantified by the wet oxidation method, with external heating, according to the methodology proposed by Yeomans and Bremner (1988), whereas total nitrogen (TN) was determined according to a methodology proposed by Tedesco et al. (1995). The carbon (CStock) and nitrogen (NStock) stocks were estimated based on the data of the TOC, TN, and BD contents, estimated from the expression:

CStock or NStock $=($ TOC or NT x BDx $\mathrm{t}) / 10$

Where: CStock or NStock represents the TOC or TN $\left(\mathrm{Mg} \mathrm{ha}^{-1}\right)$ stock; $\mathrm{C}$ or $\mathrm{N}$, indicates the TOC or $\mathrm{TN}$ content in the layer $\left(\mathrm{g} \mathrm{kg}^{-1}\right)$; BD, bulk density $\left(\mathrm{kg} \mathrm{dm} \mathrm{d}^{-3}\right)$ and $\mathrm{t}$ the thickness of the layer under analysis in m (FREIXO et al., 2002).

A mixed pasture managed area (MPM), located near the forest at an advanced stage, was also analyzed for the evaluation of the $\delta^{13} \mathrm{C}(\%)$ isotope. The pasture was formed by Brachiaria decumbens grass in the 1990's (Menezes et al., 2010). In this area, depths of $0.0-0.10$ and $0.10-0.20 \mathrm{~m}$ were also studied. The $\delta^{13} \mathrm{C}(\%)$ isotope analysis was done in spectrometer (IRMS) (Delta V Advantage) coupled to an IRMS elemental analyzer (Flash EA 2000), both from Thermo Fisher Scientific (Bremen, Germany), at the $\mathrm{C}$ and $\mathrm{N}$ Biotransformation Research Laboratory (LABCEN) of the Federal University of Santa Maria, Rio Grande do Sul, Brazil. The results were expressed as delta ${ }^{13} \mathrm{C}(\%)$, in relation to the international standard PDB (Belemnitella Americana from the Pee Dee formation), were used to evaluate the contribution of the remaining carbon of the forest $\left(\mathrm{C}_{3}\right.$ plants $)$ and that introduced by pasture (plants $\mathrm{C}_{4}$ ) in each of the areas. Calculations were performed according to Balesdent et al. (1987) using the following equations:

$$
\begin{gathered}
\mathrm{C}_{4}\left(\%^{\circ}\right)=\left(\delta{ }^{13} \mathrm{C} \mathrm{SS}-\delta{ }^{13} \mathrm{C} \mathrm{ASF} /\left(\delta{ }^{13} \mathrm{C} \text { gram }-\delta\right.\right. \\
\left.{ }^{13} \mathrm{C} \mathrm{ASF}\right) \times 100 \\
\mathrm{C}_{3}(\% \mathrm{o})=100-\mathrm{C}_{4}(\% \mathrm{o})
\end{gathered}
$$

Where: $\mathrm{C}_{4}(\%)$ is the carbon from grasses; $\mathrm{C}_{3}$ (\%) is the forest carbon from the best conservation stage (ASF); $\delta{ }^{13} \mathrm{C}$ successional stage (SS) represents the values of $\delta{ }^{13} \mathrm{C}$ of the soil samples to be evaluated (ISF and MSF); $\delta{ }^{13} \mathrm{C}$ ASF is the $\delta{ }^{13} \mathrm{C}$ of the soil from advanced stage forest (ASF); and $\delta$ ${ }^{13} \mathrm{Cgram}$ is the $\delta{ }^{13} \mathrm{C}$ of grasses collected in the pasture area $(-10.1616 \%)$.

The chemical fractionation of soil organic matter (SOM) was performed according to the differential solubility technique, using the humic fraction concepts established by the International Humic Substances Society, adapted by Benites, Madari and Machado (2003). The carbon of the humic fraction (C-Humin), the carbon of the humic acid fraction $(\mathrm{C}-\mathrm{HAF})$ and the carbon of the fulvic acid fraction (C-FAF) were determined.

The granulometric fractionation was performed according to Cambardella and Elliot (1992), in which the particulate organic matter (POM) and organic matter fractions associated with silt and clay minerals (MOM) were obtained.

\section{Statistics analysis}

The data were analyzed according to the completely randomized design and were submitted to the normal analysis of the error distribution (Lilliefors test) and homogeneity of the error variances (Cochran's Q test). The average values were compared using a t-test with Bonferroni correction $(p \leq 0.05)$. Principal component analysis (PCA) was also performed to reduce the dimensions of the data and, therefore, to facilitate the analysis, by using correlation circle graphs.

\section{RESULTS AND DISCUSSION}

\section{Soil fertility}

The evaluated areas presented differences for most of the analyzed chemical attributes. The main 
differences were observed in the 0.00-0.10 m layer (Table 1). No difference was found between the areas for potential acidity $(\mathrm{H}+\mathrm{Al})$. The layer of 0.00 $0.10 \mathrm{~m}$ presented higher fertility, with higher values of $\mathrm{pH}, \mathrm{P}, \mathrm{Ca}^{2+}, \mathrm{Mg}^{2+}, \mathrm{K}^{+}, \mathrm{S}$, and $\mathrm{V}$ and a lower value of $\mathrm{Al}^{3+}$ compared to the layer of $0.10-0.20 \mathrm{~m}$, regardless of the forest area evaluated (Table 1).

The highest fertility in the $0.00-0.10 \mathrm{~m}$ layer was explained by the constant litter input on the forest floor. In the forest ecosystems, litter production and decomposition are the main sources for supplying organic matter and nutrient transfer, which are considered key processes of the biogeochemical cycle in these systems (VITOUSEK; SANFORD, 1986; MENEZES et al., 2010). Pereira, Menezes and Schultz (2008) also verified similar results, when evaluating the litter production and decomposition of an Atlantic Forest fragment, also observed that nutrient contents in the soil were higher in the superficial layer and exhibited a decrease with depth.

Table 1. Characterization of soil fertility in different successional stages of seasonal semidecidual forest.

\begin{tabular}{|c|c|c|c|c|c|c|c|c|c|}
\hline \multirow{2}{*}{$\begin{array}{l}\text { Depth } \\
\text { (m) }\end{array}$} & \multirow{2}{*}{$\begin{array}{c}\mathrm{pH} \\
\left(\mathrm{H}_{2} \mathrm{O}\right)\end{array}$} & $\mathrm{P}$ & $\mathrm{Al}^{3+}$ & $\mathrm{Ca}^{2+}$ & $\mathrm{Mg}^{2+}$ & $\mathrm{K}^{+}$ & $\mathrm{H}+\mathrm{Al}$ & $\mathrm{S}$ & $\mathrm{V}$ \\
\hline & & $\mathrm{mg} \mathrm{kg}^{-1}$ & & \multicolumn{5}{|c|}{ 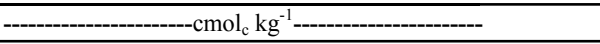 } & $\%$ \\
\hline & \multicolumn{9}{|c|}{ ISF } \\
\hline $0.00-0.10$ & $5.05 \mathrm{Aa}$ & $2.2 \mathrm{Ab}$ & $1.09 \mathrm{Bb}$ & $1.06 \mathrm{Ab}$ & $1.02 \mathrm{Ab}$ & $0.18 \mathrm{Ab}$ & $5.65 \mathrm{Aa}$ & $2.28 \mathrm{Ab}$ & $28.87 \mathrm{Ab}$ \\
\hline \multirow[t]{2}{*}{$0.10-0.20$} & $4.79 \mathrm{~B} \mathrm{a}$ & $1.0 \mathrm{Bb}$ & $2.00 \mathrm{Ab}$ & $0.22 \mathrm{Ba}$ & $0.36 \mathrm{Bb}$ & $0.07 \mathrm{Bb}$ & $5.23 \mathrm{Aa}$ & $0.66 \mathrm{Ba}$ & $11.29 \mathrm{Bb}$ \\
\hline & \multicolumn{9}{|c|}{ MSF } \\
\hline $0.00-0.10$ & $5.38 \mathrm{Aa}$ & $2.2 \mathrm{Ab}$ & $0.46 \mathrm{Bb}$ & $2.77 \mathrm{Aa}$ & $2.10 \mathrm{Aa}$ & $0.37 \mathrm{Aa}$ & $4.50 \mathrm{Aa}$ & $5.31 \mathrm{Aa}$ & $53.22 \mathrm{Aa}$ \\
\hline \multirow[t]{2}{*}{$0.10-0.20$} & $4.93 \mathrm{Ba}$ & $1.2 \mathrm{Bb}$ & $1.65 \mathrm{Ab}$ & $0.57 \mathrm{Ba}$ & $0.87 \mathrm{Ba}$ & $0.23 \mathrm{Ba}$ & $4.99 \mathrm{Aa}$ & $1.73 \mathrm{Ba}$ & $25.65 \mathrm{Ba}$ \\
\hline & \multicolumn{9}{|c|}{ ASF } \\
\hline $0.00-0.10$ & $4.14 \mathrm{Ab}$ & 4.2 Aa & $1.17 \mathrm{Ba}$ & $1.60 \mathrm{Ab}$ & $0.99 \mathrm{Ab}$ & $0.22 \mathrm{Aab}$ & $5.89 \mathrm{Aa}$ & $2.83 \mathrm{Ab}$ & $32.22 \mathrm{Ab}$ \\
\hline $0.10-0.20$ & $4.22 \mathrm{Ab}$ & $2.4 \mathrm{Ba}$ & $2.52 \mathrm{Aa}$ & $0.63 \mathrm{Ba}$ & $0.54 \mathrm{Ba}$ & $0.11 \mathrm{Bab}$ & $5.39 \mathrm{Aa}$ & $1.29 \mathrm{Ba}$ & $19.41 \mathrm{Ba}$ \\
\hline
\end{tabular}

Means followed by the same letter in the column did not differ by the Bonferroni test at $5 \%$ (lowercase among successional stages in the same depth; uppercase among depths at the same successional stage). ISF - initial stage forest; MSF - medium stage forest; ASF - advanced stage forest.

In the ISF area, the lowest available $\mathrm{P}(0.00$ $0.20 \mathrm{~m})$ and $\mathrm{Mg}^{2+}$ contents, and $\mathrm{V} \%(0.10-0.20 \mathrm{~m})$ were quantified in comparison to the ASF area, as well as lower values of $\mathrm{Ca}^{2+}(0.00-0.10 \mathrm{~m}), \mathrm{Mg}^{2+}$ $(0.00-0.20 \mathrm{~m}), \mathrm{K}^{+}(0.00-0.20 \mathrm{~m}), \mathrm{S}(0.00-0.10 \mathrm{~m})$, and $\mathrm{V} \%(0.00-0.20 \mathrm{~m})$ than the MSF area (Table 1$)$. The lower soil fertility in the ISF area can be attributed to lower litter production, as presented by Machado et al. (2015), as well as the long history of use as pasture, which preceded the beginning of the forest succession. Previous soil management, without the use of liming and fertilization, and the removal of bases from the system through cattle grazing, may have reduced soil fertility in ISF. Thus, it is assumed that these losses could not yet be compensated for by the organic matter input of this initial successional stage (GUARESHI et al., 2014).

In the ASF area, the lowest values of $\mathrm{pH}$ $(0.00-0.20 \mathrm{~m})$ and higher levels of $\mathrm{Al}^{3+}(0.00-0.20$ $\mathrm{m})$ were quantified, compared to the forest areas with the shortest succession time (Table 1). In this area, the lowest levels of $\mathrm{Ca}^{2+}, \mathrm{Mg}^{2+}, \mathrm{S}$, and $\mathrm{V} \%$ values were also observed in the 0.00-0.10 m layer when compared to the MSF area. The lowest values of bases in the ASF may be related to the immobilization of these elements in the trunks of large trees (DAVIDSON et al., 2007) that predominate in the area, which may be reflected in the lower values of soil bases. In addition, acidification may occur in this environment caused by the release of humic substances from decomposing plant material. Machado et al. (2015) found higher litter production and higher leaf decomposition rates in the advanced stage, which may explain the lower $\mathrm{pH}$ values in the ASF.

The higher levels of available $\mathrm{P}$ from the ASF area compared to the ISF and MSF areas may be a consequence of higher levels of FAF and FHA (Table 4), because according to Guppy et al. (2005), the competitive adsorption between phosphorus and organic acids by soil adsorption sites results in an increase in $\mathrm{P}$ concentration in the solution. In addition, organic acids of high molecular mass, such as fulvic and humic acids, can further complex metal cations, such as $\mathrm{Fe}$ and $\mathrm{Al}$, from the surface of the colloids in the soil, reducing the number of adsorption sites, thus increasing the availability of this nutrient to the plants (GUPPY et al., 2005).

\section{Bulk density and stocks of carbon and nitrogen}

The values of bulk density (BD) were lower in the oldest area of succession (ASF) in comparison to the other areas evaluated (Table 2). The lower value of density in the ASF area was related to the improvements in physical attributes of the soil, such as aggregation, provided by the increase in TOC as a function of the succession time. Santos et al. (2010) also verified lower values of density in the surface layers of different toposequences in environments of 
'Mar de Morros', in Pinheiral - RJ, which were related to the constant deposition of vegetal residues on the surface of the soil. Guareschi et al. (2014) reports that the highest values of density of the areas with the shortest succession time can be attributed to the short time of establishment of the younger areas where the development of the plant community has not yet been able to reduce the impacts on aggregation and density caused by the agricultural cycles that preceded them.

Table 2. Bulk density (BD), Total Organic Carbon (TOC), Total Nitrogen (TN) and Total Stocks of Carbon (CStock) and Nitrogen (NStock), in different successional stages of seasonal semidecidual forest.

\begin{tabular}{|c|c|c|c|c|c|}
\hline \multirow{2}{*}{$\begin{array}{l}\text { Depth } \\
(\mathrm{m})\end{array}$} & BD & TOC & NT & CStock & NStock \\
\hline & $\mathrm{kg} \mathrm{dm}^{-3}$ & \multicolumn{2}{|c|}{ - $\mathrm{g} \mathrm{kg}^{-1}$} & \multicolumn{2}{|c|}{ - $\mathrm{Mg} \mathrm{ha}^{-1}$} \\
\hline \multicolumn{6}{|c|}{ ISF } \\
\hline $0.00-0.10$ & $1.24 \mathrm{Ba}$ & $28.53 \mathrm{Ab}$ & $0.94 \mathrm{Ab}$ & $35.47 \mathrm{Ab}$ & $1.18 \mathrm{Ab}$ \\
\hline $0.10-0.20$ & $1.41 \mathrm{Aa}$ & $19.65 \mathrm{Bb}$ & $0.49 \mathrm{Bb}$ & $27.87 \mathrm{Bb}$ & $0.70 \mathrm{Bb}$ \\
\hline \multicolumn{6}{|c|}{ MSF } \\
\hline $0.00-0.10$ & $1.29 \mathrm{Ba}$ & $38.29 \mathrm{Aa}$ & $1.44 \mathrm{Aa}$ & $49.58 \mathrm{Aa}$ & $1.87 \mathrm{Aa}$ \\
\hline $0.10-0.20$ & $1.37 \mathrm{Aa}$ & $24.06 \mathrm{Ba}$ & $0.98 \mathrm{Ba}$ & $33.01 \mathrm{Ba}$ & $1.35 \mathrm{Ba}$ \\
\hline \multicolumn{6}{|c|}{ ASF } \\
\hline $0.00-0.10$ & $1.17 \mathrm{Bb}$ & $40.59 \mathrm{Aa}$ & $1.23 \mathrm{Aa}$ & $47.54 \mathrm{Aa}$ & $1.45 \mathrm{Aa}$ \\
\hline $0.10-0.20$ & $1.29 \mathrm{Ab}$ & $21.70 \mathrm{Ba}$ & $1.03 \mathrm{Ba}$ & $28.52 \mathrm{Ba}$ & $1.35 \mathrm{Ba}$ \\
\hline
\end{tabular}

Means followed by the same letter in the column did not differ by the Bonferroni test at $5 \%$ (lowercase among successional stages in the same depth; uppercase among depths at the same successional stage). ISF - initial stage forest; MSF - medium stage forest; ASF - advanced stage forest.

Regardless of the area evaluated, higher levels and $\mathrm{C}$ and $\mathrm{N}$ stocks, as well as lower values of soil density were quantified in the $0.0-0.10 \mathrm{~m}$ layer compared to $0.10-0.20 \mathrm{~m}$ (Table 2). These results can also be attributed to the constant deposition of plant material on the soil surface, which causes an increase in the $\mathrm{C}$ and $\mathrm{N}$ stocks in the superficial layers in relation to the subsurface. The accumulation of organic material in the surface layers favors an improvement of the aggregation and increase of porosity, and consequently, lower values of soil density. Similar results were presented by Guareschi et al. (2014) who also verified this pattern when evaluating areas of secondary forest with different years of succession in the Atlantic Forest region in the state of Rio de Janeiro.

The MSF and ASF areas, regardless of depth evaluated, had higher levels and $\mathrm{C}$ and $\mathrm{N}$ stocks compared to the ISF area (Table 2). These results indicate that, as a function of the forest succession time, there is an increase in the $\mathrm{C}$ and $\mathrm{N}$ stocks, which can be attributed to the structural complexity of the vegetation, mainly in terms of density and basal area, which in turn may influence the deposition and accumulation of litter. Menezes et al. (2010); Machado et al. (2015) when evaluating the same areas as in this study verified greater litter production in the advanced stage area. Moreover, the greater number of plant species in advanced stages may contribute to organic material with different qualities (e.g., $\mathrm{C} / \mathrm{N}$ ratio, lignin) (OSTERTAG et al., 2008), allowing for increases in SOM content. Similarly, Silva et al. (2012) when evaluating the TOC of secondary forest areas in the initial, intermediate, and advanced stages also showed higher $\mathrm{C}$ values in the older area, attributing the result to the greater amount of vegetal residues produced by the forest species, as well as to the efficient cycling of nutrients occurring in these areas.

\section{Isotope $\delta{ }^{13} \mathrm{C}(\%$ )}

The $\delta^{13} \mathrm{C}$ isotope values (\%o) showed that, regardless of the depth evaluated, the contribution of TOC from the MPM $\left(\mathrm{C}_{4}\right)$ that preceded the implantation of the secondary forests was reduced tending to zero as a function of forest succession time (Figure 1a,b).

The results of the ${ }^{13} \mathrm{C}$ isotope showed that as a function of the time of succession, the secondary forests were able to increase the carbon stock of the soil $\left(\mathrm{C}_{3}\right.$ plant carbon), which could restore the conditions that favor the succession process. A similar pattern was also observed by Marin-Spiotta et al. (2009), when studying the dynamics of ${ }^{13} \mathrm{C}$ in the substitution of pasture by secondary forests in Puerto Rico. The authors evaluated areas with ages of $10,20,30$, and 80 years of succession and verified carbon substitution of $\mathrm{C}_{4}$ plants by carbon of $\mathrm{C}_{3}$ plants according to successional progression. These results also confirm the assumption that as secondary forest formations advance over pasture areas, there is a progressive decrease of ${ }^{13} \mathrm{C}$ in the soil surface layers. This fact is due to the increase of the entry of organic material from $\mathrm{C}_{3}$ plants (poorer in ${ }^{13} \mathrm{C}$ ) that predominate in the flora of these formations. The decreasing pattern of ${ }^{13} \mathrm{C}$ in depth was also observed in the Amazon Forest (VIDDOTTO et al., 2007). These studies also demonstrated the greater influence of plants with $\mathrm{C}_{3}$ photosynthetic cycle on the organic matter input to the superficial layers of the soil in areas under medium and advanced stages of forest succession, and of the plants of the $\mathrm{C}_{4}$ cycle in the areas under initial stage of succession and 
pasture. The replacement of pasture by the natural succession process is altering soil $\mathrm{C}$ dynamics, because after 20 years of succession, the ISF area presents $68 \%$ of the $\mathrm{C}$ of the soil from $\mathrm{C}_{3}$ plants, the area of MSF after 25 years was $97.1 \%$, and the area of ASF after 60 years was $100 \%$ carbon from $\mathrm{C}_{3}$ plant origin (forest). These results demonstrate the potential of these areas in converting and storing organic carbon in the soil, even in the process of natural succession, which may contribute to soil stability, mainly because of erosion processes.

(a)

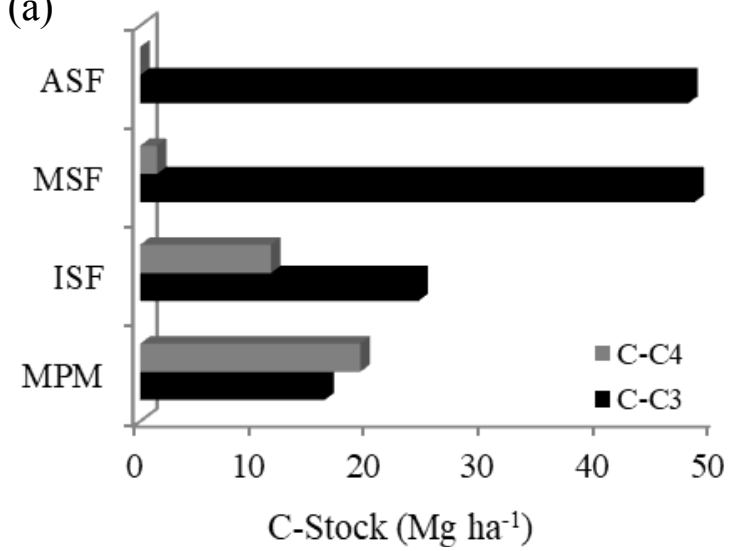

\section{The SOM granulometry fractioning}

Regarding the levels of particulate organic matter (POM) and organic matter associated with minerals (MOM), it can be observed that both the highest values occurred in the superficial layer $(0.00$ $0.10 \mathrm{~m}$ ) (Table 3). As to the $\mathrm{C}$ and $\mathrm{N}$ stocks data, these results can also be attributed to the higher contribution of litter organic residues, and consequently, of SOM at the soil surface. Furthermore, the absence of soil rotation also contributes to the stabilization process of organic matter in the soil.

(b)

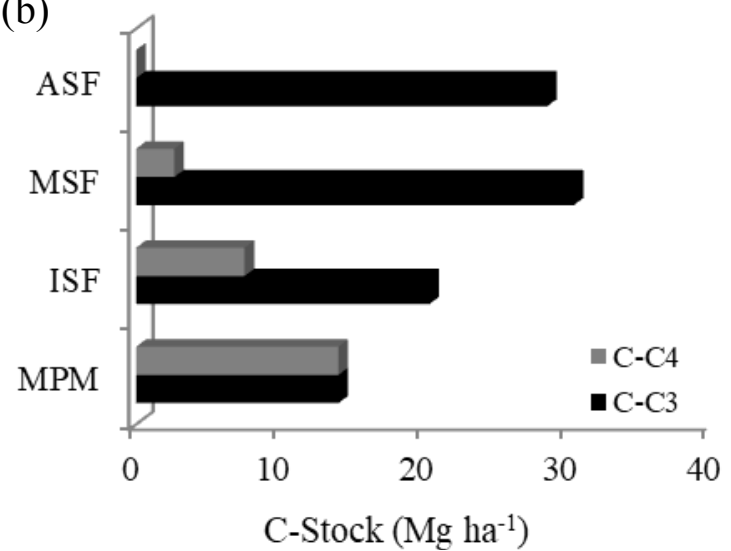

Figure 1. Contribution of remaining carbon from the forest $\left(\mathrm{C}_{3}\right.$-plants $)$ and carbon from the grass $\left(\mathrm{C}_{4}\right.$-plants $)$ in carbon stock $\left(\mathrm{Mg} \mathrm{ha}^{-1}\right)$. (a) 0.00-0.10 m and (b) 0.10-0.20 m. ISF - initial stage forest; MSF - medium stage forest; ASF - advanced stage forest; MPM- mixed pasture managed.

Table 3. Granulometric SOM fractions in different successional stages of seasonal semidecidual forest.

\begin{tabular}{|c|c|c|c|c|}
\hline $\begin{array}{c}\text { Depth } \\
\text { (m) }\end{array}$ & POM & $\% \mathrm{C}$ & MOM & $\% \mathrm{C}$ \\
\hline \multicolumn{5}{|c|}{ ISF } \\
\hline $\begin{array}{l}0.00-0.10 \\
0.10-0.20\end{array}$ & $\begin{array}{l}6.07 \mathrm{Aa} \\
2.47 \mathrm{Ba}\end{array}$ & $\begin{array}{l}21.10 \\
12.47\end{array}$ & $\begin{array}{l}22.46 \mathrm{Ab} \\
17.18 \mathrm{Bb}\end{array}$ & $\begin{array}{l}78.90 \\
87.53\end{array}$ \\
\hline \multicolumn{5}{|c|}{ MSF } \\
\hline $0.00-0.10$ & $6.48 \mathrm{Aa}$ & 16.54 & $31.81 \mathrm{Aa}$ & 83.46 \\
\hline $0.10-0.20$ & $3.68 \mathrm{Ba}$ & 15.96 & $20.37 \mathrm{Ba}$ & 84.04 \\
\hline \multicolumn{5}{|c|}{ ASF } \\
\hline $0.00-0.10$ & $5.04 \mathrm{Aa}$ & 12.11 & $35.55 \mathrm{Aa}$ & 87.89 \\
\hline $0.10-0.20$ & $2.73 \mathrm{Ba}$ & 13.18 & $18.96 \mathrm{Ba}$ & 86.82 \\
\hline
\end{tabular}

Means followed by the same letter in the column did not differ by the Bonferroni test at $5 \%$ (lowercase among successional stages in the same depth; uppercase among depths at the same successional stage ). ISF - initial stage forest; MSF - medium stage forest; ASF - advanced stage forest; POM: particulate organic matter; MOM: organic matter associated to mineral.

There were no differences in the POM levels between the study areas, regardless of the analyzed depth. This pattern is caused by the microclimate conditions and the nature of the litter forming substrate, which favors biological activity as a whole, resulting in higher rates of decomposition, which may be rapidly converting POM into MOM. These results can be better visualized by the high MOM values in relation to TOC $(\% \mathrm{C})$ (Table 3$)$.

According to Figueiredo, Resck and Carneiro (2010), to have higher levels of MOM in the soil, it is necessary to increase the POM content for later association with the soil minerals in the silt and clay sizes. Moreover, the higher $\% \mathrm{C}$ of $\mathrm{MOM}$ relative to POM can be attributed to the great recalcitrance of this fraction, because it interacts with the surface of the mineral particles forming organomineral complexes protected by the colloidal protection mechanism (SÁ; LAL, 2009; LOSS et al., 2011; ROSSI et al., 2012). Marin-Spiotta et al. (2009), when assessing soil carbon dynamics in areas with different successional ages in Costa Rica, also found higher proportions of $\mathrm{C}$ in the fraction associated with silt and clay minerals, in which values ranged from 78.3 to $85.7 \%$.

The MOM values coincide with the pattern of 
C content and stock results, where, regardless of the depth evaluated, the MSF and ASF areas present higher levels in comparison to the ISF area. Associating this result with the high values of $\% \mathrm{C}$ makes it noticeable that with the advancement of the successional process, the carbon is being widely stocked in association with the silt and clay minerals. In this study, MOM was sensitive to detect changes in soil carbon because of the successional progression, which may make this attribute a good indicator of changes in land use.

\section{SOM chemical fractioning}

From the quantified humic fractions, the highest levels were verified for Humin, regardless of the area evaluated and depth studied (Table 4).

Table 4. Humic SOM fractions in different successional stages of seasonal semidecidual forest.

\begin{tabular}{cccc}
\hline \multirow{2}{*}{$\begin{array}{c}\text { Depth } \\
(\mathrm{m})\end{array}$} & C-Hum & C-FAF & C-HAF \\
\cline { 2 - 4 } & & - & ISF \\
\hline & & $2.75 \mathrm{Ab}$ & \\
\hline $0.00-0.10$ & $12.26 \mathrm{Aa}$ & $2.82 \mathrm{Aa}$ & \\
\hline $0.10-0.20$ & $6.04 \mathrm{Ba}$ & $\mathrm{MSF}$ & $2.26 \mathrm{Aa}$ \\
\hline $0.00-0.10$ & & $1.83 \mathrm{Ab}$ & $1.39 \mathrm{Ab}$ \\
$0.10-0.20$ & $15.25 \mathrm{Aa}$ & $2.84 \mathrm{Aa}$ & $2.92 \mathrm{Aa}$ \\
\hline & $7.35 \mathrm{Ba}$ & $\mathrm{ASF}$ & \\
\hline $0.00-0.10$ & & $3.83 \mathrm{Aa}$ & $3.83 \mathrm{Aa}$ \\
$0.10-0.20$ & $11.06 \mathrm{Aa}$ & $1.97 \mathrm{Ba}$ & $1.40 \mathrm{Ba}$ \\
\hline
\end{tabular}

Means followed by the same letter in the column did not differ by the Bonferroni test at 5\% (lowercase among successional stages in the same depth; uppercase among depths at the same successional stage ). ISF - initial stage forest; MSF - medium stage forest; ASF - advanced stage forest; C-HUM: carbon in the humin fraction; C-FAF: carbon in the fulvic acid fraction; C-HAF: carbon in the humic acid fraction.

In other studies on tropical soils, the carbon of the Humin fraction is also predominant in relation to the other fractions (FONTONA et al., 2005; FONTONA et al., 2006; ROSSI et al., 2012). The high carbon values of Humin are related to the size of the molecules and to their greater degree of stability (FONTONA et al., 2005). According to Fontana et al. (2006), FAF and FHA fractions have lower stability, which allow them to be translocated to deeper layers, be polymerized or mineralized, and thus reduce their residual content in the soil. Giácomo, Pereira and Balieiro (2008) also found a pattern of higher $\mathrm{C}$ content in Humin in secondary forests with more than 30 years, in Seropédica, RJ, with contents were $5.73 \mathrm{~g} \mathrm{~kg}^{-1}$ in the $0.00-0.10 \mathrm{~m}$ layer.

The carbon of the Humin fraction did not differ between the successional stages evaluated (Table 4). Similar results were reported by Diniz (2011), who evaluated areas of secondary forests with different stages of succession and did not find differences in Humin between the areas, such results were attributed to the fact that this fraction is very stable in the soil. Another possible explanation for the same values of Humin between the areas may be associated with the stabilization capacity of this material in the soil, where both areas have already reached their maximum capacity.

No differences were found for FAF and FHA values between depths in the areas of MSF and ISF, whereas in ASF these were also higher in the most superficial layer. This pattern may also be caused by the greater organic material input to the soil surface. The ASF area presented higher FAF and FHA values compared to ISF and MSF areas at the $0.00-0.10 \mathrm{~m}$ depth (Table 4). This result may also reflect the greater succession time of ASF, which inputs to the soil the vegetal residues of a greater diversity of species, that is, the greater contribution of residues whose chemical composition is more heterogeneous and may cause the greater formation of these fractions of the SOM, as previously reported. Diniz (2011) also verified higher carbon contents of the humic and fulvic acid fractions in the secondary forest of intermediate succession in comparison to the forest with initial succession, attributing the results to the greater diversity of vegetal species in the area with more time of succession.

Based on the results obtained from the chemical fractionation it was possible to observe a pattern similar to that found by the physical fractionation. The higher levels of organic carbon were associated with the most recalcitrant forms, such as silt and clay fractions in the physical fractionation and the Humin fraction in the chemical fractionation. Thus, in view of the results obtained by soil organic fractionation methods, it is evident that these areas have the potential to sequester carbon in the soil. The more stable fractions of $\mathrm{C}$ contribute to soil maintenance by improving the 
physical and chemical attributes. Therefore, the conservation of these forest remnants is of great importance for the maintenance and storage of organic carbon in the soil.

\section{Multivariate analysis}

(a)

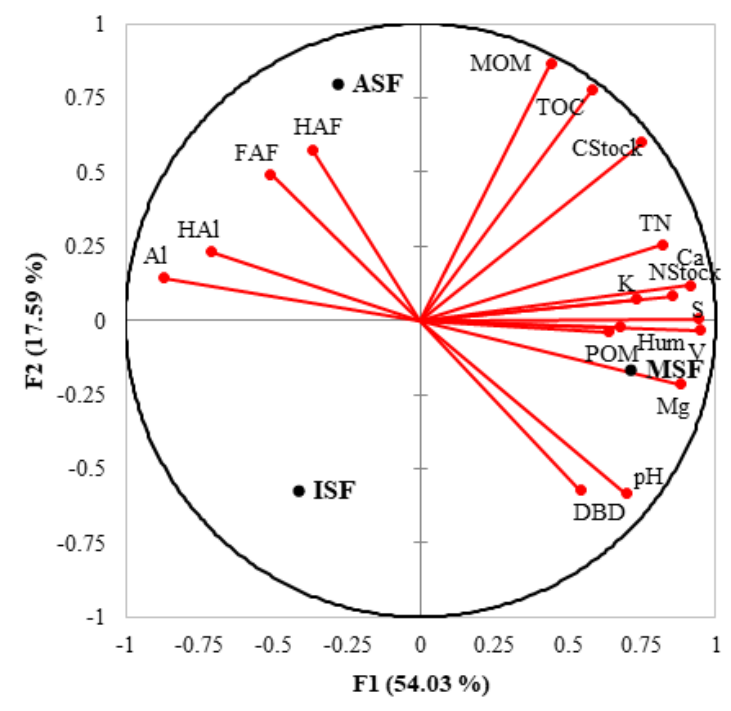

The principal component analysis (PCA) based on the results obtained in this study, separated the evaluated areas according to the chemical and physical attributes evaluated at the depths of 0.00 0.10 and $0.10-0.20 \mathrm{~m}$ (Figure $2 \mathrm{a}, \mathrm{b}$ ).

(b)

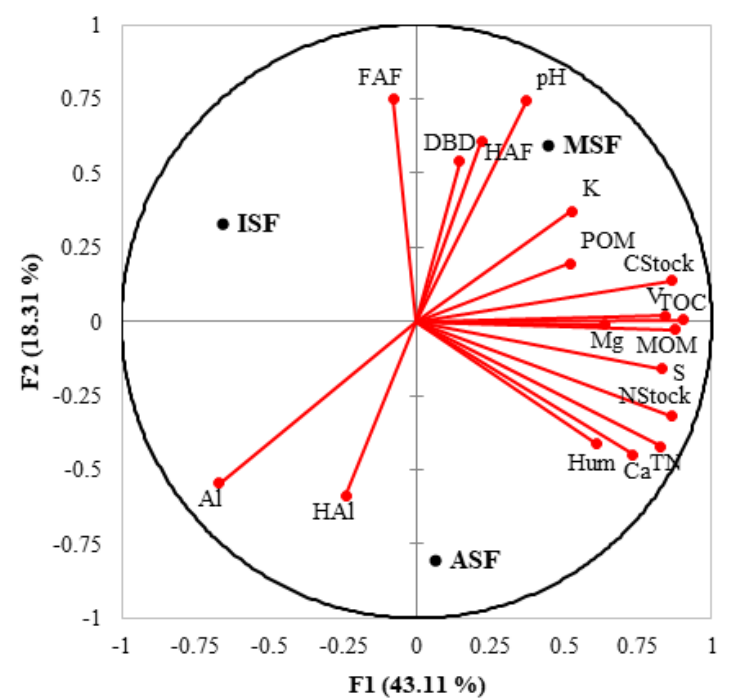

Figure 2. Ordering diagrams produced by principal component analysis of the samples collected in the $0.00-0.10 \mathrm{~m}$ (a) and 0.10-0.20 m (b) depths. ). ISF - initial stage forest; MSF - medium stage forest; ASF - advanced stage forest.

For the PCA, the parameters evaluated in this study were represented by arrows that indicated the direction of greater variability of each parameter, whereas the length of the arrow is proportional to the percentage of the variance of this parameter represented by the principal components, and the projection of these vectors in each axis is the correlation of this parameter with each principal component. In this sense, the positive vectors (Figure $2 \mathrm{a}, \mathrm{b})$ in the direction of the F1 axis, close to the MSF area, are grouped. These clusters demonstrate once again that the greater succession time and SOM contents of the MSF and ASF areas compared to that of the ISF area provide improvements to the soil chemical and physical attributes

\section{CONCLUSIONS}

In this study, it was possible to prove the effect of the successional stage of the forest on the organic matter dynamics and soil fertility. It was verified that forests in more advanced stages of succession present higher values of carbon and nitrogen stocks, carbon stability and soil fertility, than the forest in the initial stage. These results are mainly attributed to the quantity and quality of the litter input.

Among the evaluated attributes, this study highlights the carbon and nitrogen stocks, the ${ }^{13} \mathrm{C}$ isotope, the carbon associated with the silt and clay minerals, the fulvic acid fraction, and the humic acid fraction, variables that were sensitive to changes as the successional process progressed and could thus be used as indicators of environmental quality.

This study also highlighted the importance of these forests, which even in successional stages, have a significant role in the storage and stability of carbon in the soil, which makes them areas of great importance for conservation.

\section{REFERENCES}

AB'SABER, A. Domínios morfoclimáticos e solos do Brasil. In: ALVAREZ V.; V. H.; FONTES L. E. F.; FONTES, M. P. F. (Eds.). Os solos nos grandes domínios morfoclimáticos do Brasil e o desenvolvimento sustentável. Viçosa, MG, Sociedade Brasileira de Ciência do Solo/ Universidade Federal de Viçosa, 1996. p. 1-18.

ALVARES, C. A.; STAPE, J. L.; SENTELHAS, P. C. Köppen's climate classification map for Brazil. Meteorologische Zeitschrift, v. 22, n. 6, p. 711-728, 2013.

BENITES, V. M.; MADARI, B.; MACHADO, P. L. O. A. Extração e fracionamento quantitativo de substâncias húmicas do solo: um procedimento 
simplificado de baixo custo. Rio de Janeiro, Embrapa, 2003. 7 p. (Comunicado Técnico, 16).

CAMBARDELLA, C. A.; ELLIOTT, E. T. Particulate soil organic matter changes across a grassland cultivation sequence. Soil Science Society of America Journal, v. 56, n. 3, p. 777-783, 1992.

CHAZDON, R. Regeneração de florestas tropicais. Boletim do Museu Paraense Emílio Goeldi. Ciências Naturais, v. 7, n. 3, p. 195-218, 2012.

DAVIDSON, E. A. et al. Recuperation of nitrogen cycling in Amazonian forests following agricultural abandonment. Nature, v. 447, s/n, p. 995-998, 2007.

DINIZ, J. S. Teores de glomalina e substâncias húmicas em diferentes estágios sucessionais de floresta seca. 2011. 32 f. Dissertação (Mestrado em Fitossanidade e Biotecnologia Aplicada) Universidade Federal Rural do Rio de Janeiro, Seropédica, 2011.

DONAGEMMA, G. K. et al. Manual de métodos de analise de solo. 2. ed. Rio de Janeiro, RJ: Embrapa, 2011.

FIGUEIREDO, C. C.; RESCK, D. V. S.; CARNEIRO, M. A. C. Labile and stable fractions of soil organic matter under management systems and native cerrado. Revista Brasileira de Ciência do Solo, v. 34, s/n, p. 907-916, 2010.

FONTANA, A. et al. Fracionamento químico da matéria orgânica em solo sob diferentes coberturas vegetais em Sooretama (ES). Magistra, v. 17, n. 3, p. $135-141,2005$.

FONTANA, A. et al. Atributos de fertilidade e frações húmicas de um Latossolo Vermelho no Cerrado. Pesquisa Agropecuária Brasileira, v. 41, n. 5 , p. $847-853,2006$.

FREIXO, A. A. et al. Estoques de carbono e nitrogênio e distribuição de frações orgânicas de Latossolo do Cerrado sob diferentes sistemas de cultivo. Revista Brasileira de Ciência do Solo, v. 26, s/n, p. 425-434, 2002.

GAMFELDT, L. et al. Higher levels of multiple ecosystem services are found in forests with more tree species. Nature Communications, v. 4, s/n, p. 1340, 2013.

GIÁCOMO, R. G.; PEREIRA, M. G.; BALIEIRO, F. C. Estoques de carbono e nitrogênio e distribuição das frações húmicas no solo sob diferentes coberturas florestais. Revista Brasileira de Ciências Agrárias, v. 3, n. 1, p. 42-48, 2008.
GUARESCHI, R. F. et al. Atributos químicos e físicos do solo sob pastagem e estádios sucessionais de floresta estacional. Revista de la Facultad de Agronomía, v. 113, n. 1, p. 1-24, 2014.

GUARIGUATA, M. R.; OSTERTAG, R. Neotropical secondary succession: changes in structural and functional characteristics. Forest Ecology and Management, v. 148, s/n, p. 85-206, 2001 .

GUPPY, C. N. et al. Competitive sorption reactions between phosphorus and organic matter in soil: A review. Australian Journal of Soil Research, v. 43 , n. 2, 189-202, 2005 .

INSTITUTO BRASILEIRO DE GEOGRAFIA E ESTATÍSTICA - IBGE. Manual técnico da vegetação brasileira. 2 ed. Rio de Janeiro, 2012. $271 \mathrm{p}$.

LAL, R. Forest soils and carbon sequestration. Forest Ecology and Management, v. 220, s/n, p. 242-258, 2005

LOSS, A. et al. Frações orgânicas e índice de manejo de carbono do solo em diferentes sistemas de produção orgânica. Idesia, v. 29, n. 2, p. 11-19, 2011 .

LOSS, A. et al. Particulate organic matter in soil under different management systems in the Brazilian Cerrado. Soil Research, v. 50, s/n, p. 685-693, 2012.

MACEDO, M. O. et al. Changes in soil $\mathrm{C}$ and $\mathrm{N}$ stocks and nutrient dynamics 13 years after recovery of degraded land using leguminous nitrogen-fixing trees. Forest Ecology and Management, v. 255, s/ n, p. 1516-1524, 2008.

MACHADO, D. L. et al. Ciclagem de nutrientes em diferentes estágios sucessionais da Mata Atlântica na Bacia do rio Paraíba do Sul, RJ. Bioscience Journal, v. 31, n. 4 , p. 1222-1237, 2015.

MACHADO, R. L. et al. Soil and nutrient losses in erosion gullies at different degrees of restoration. Revista Brasileira de Ciência do Solo, v. 34, s/n, p. 945-954, 2010

MARIN-SPIOTTA, E. et al.. Soil organic matter dynamics during 80 years of reforestation of tropical pastures. Global Change Biology, v. 15, n. 6, p. 1584-1597, 2009.

MENEZES, C. E. G. et al. Aporte e decomposição da serapilheira e produção de biomassa radicular em florestas com diferentes estágios sucessionais em Pinheiral, RJ. Ciência Florestal, v. 20, n. 3, p. 439452,2010 
OSTERTAG, R. et al. Litterfall and decomposition in relation to soil carbon pools along a secondary forest chronosequence in Puerto Rico. Ecosystems, v. 11, s/n, p. 701-714, 2008.

PEREIRA, M. G.; MENEZES, L. F. T.; SCHULTZ, N. Aporte e decomposição da serapilheira na floresta atlântica, Ilha da Marambaia, Mangaratiba, RJ. Ciência Florestal, v. 18, n. 4, p. 443-454, 2008.

ROCHA JUNIOR, P. R. et al. Can soil organic carbon pools indicate the degradation levels of pastures in the Atlantic Forest biome? Journal of Agricultural Science, v. 6, n. 1, p. 84-95, 2014.

ROSSI, C. Q. et al. Frações lábeis da matéria orgânica em sistema de cultivo com palha de braquiária e sorgo. Revista Ciência Agronômica, v. 43, n. 1, p. 38-46, 2012.

SÁ, J. C. M.; LAL, R. Stratification ratio of soil organic matter pools as an indicator of carbon sequestration in a tillage chronosequence on a Brazilian Oxisol. Soil Tillage Research, v. 103, s/n, p. 46-56, 2009.

SANTOS, A. C. et al. Gênese e classificação de solos numa topossequência no ambiente de Mar de Morros do Médio Vale do Paraíba do Sul, RJ. Revista Brasileira de Ciência do Solo, v. 34, s/n, p. 1297-1314, 2010.

SANTOS, H. G.; JACOMINE, P. K. T.; et al. Sistema Brasileiro de Classificação de Solos. 3. ed. Rio de Janeiro, RJ: Embrapa Solos, 2013. v. 1. 2013. $353 \mathrm{p}$.

SCHEDLBAUER, J. L.; KAVANAGH, K. L. Soil carbon dynamics in a chronosequence of secondary forests in northeastern Costa Rica. Forest Ecology and Management, v. 255, s/n, p. 1326-1335, 2008.

SILVA, C. F. et al. Carbono orgânico total, biomassa microbiana e atividade enzimática do solo de áreas agrícolas, florestais e pastagem no Médio Vale do Paraíba do Sul (RJ). Revista Brasileira de Ciência do Solo, v. 36, n. 6, p. 1680-1689, 2012.

TEDESCO, M. J. et al. Análise de solo, plantas e outros materiais. 2.ed. Porto Alegre, RS, Universidade Federal do Rio Grande do Sul, 1995. $174 \mathrm{p}$.

VIDDOTTO, E. et al. Dinâmica do ecótono florestacampo no sul do estado do Amazonas no Holoceno, através de estudos isotópicos e fitossociológicos. Acta Amazônica, v. 37, n. 3, p. 385-400, 2007.
VITOUSEK, P. M.; SANFORD, R. L. Nutrient cycling in moist tropical forest. Annual Review of Ecology and Systematics, v. 17, s/n, p. 137-167, 1986.

YEOMANS, J. C.; BREMNER, J. M. A rapid and precise method for routine determination of organic carbon in soil. Communications in Soil Science and Plant Analysis, v. 19, n. 13, p. 1467-1476, 1988.

WANG, F. et al. Effects of nitrogen-fixing and nonnitrogen-fixing tree species on soil properties and nitrogen transformation during forest restoration in southern China. Soil Science and Plant Nutrition, v. 56, s/n, p. 297-306, 2010.

ZUO, X. et al. Changes in carbon and nitrogen storage along a restoration gradient in a semiarid sandy grassland. Acta Oecologica, Montrouge, v. 69, s/n, p. 1-8, 2015. 